\title{
SOCIO-DEMOGRAPHIC CHARACTERISTICS AS DETERMINANTS OF DIFFERENCES IN PERCEPTION OF LOCAL GASTRONOMY ${ }^{1}$
}

\author{
Nikola Vuksanovič², Dragan Tešanovič3 ${ }^{3}$ Bojana Kalenjuk, Milijanko Portič \\ Marija Kneževićc
}

\begin{abstract}
This study aims to research differences in socio-demographic characteristics of foreign tourists in consumption of local food in the city centres Belgrade and Novi Sad, Republic of Serbia. The research was conducted on a sample of 673 respondents. The results of this study point out the importance of socio-demographic variables in research of local gastronomy as a significant component of tourism product. The research included the determining of the impact of the city the tourists stayed at. The differences were examined via two-factor ANOVA analysis of variance. The obtained results indicate that there are differences between age groups, in the level of education, monthly income and countries that foreign tourists come from, whereas there is no difference between genders in relation to the perception of local gastronomy. At the same time, the findings indicate that there are no differences in the perception of local gastronomy between the cities of Novi Sad and Belgrade. The results confirm previous studies and point out the significance of socio-demographic characteristics
\end{abstract}

1 This Research Paper was the part of the projects No. 46009 and 46005, financed by Serbian Ministry of Education, Science and Technological Development.

2 Nikola Vuksanović, M.Sc., Teaching Assistant, Higher education school for management and business communication, Department of Hospitality, Mitropolita Stratimirovića Street no. 110, 21205 Sremski Karlovci, Republic of Serbia, Phone: +381 631968 770; E-mail: vuksanovicnikola@yahoo.com

3 Dragan Tešanović Ph.D., Full Professor, University of Novi Sad, Faculty of Science, Department of Geography, Tourism and Hotel Management, Dositeja Obradovića Square no. 3, 21000 Novi Sad, Republic of Serbia, Phone: +381 63541 436, E-mail: tesanovic.dragan@gmail.com

4 Bojana Kalenjuk Ph.D., Associate Professor, University of Novi Sad, Faculty of Sciences, Department of Geography, Tourism and Hotel Management, Dositeja Obradovića Square no. 3, 21000 Novi Sad, Republic of Serbia, Phone: +381 641990 235, E-mail: bojanakalenjuk@yahoo.com

5 Milijanko Portić Ph.D., Associate Professor, University of Novi Sad, Faculty of Science, Department of Geography, Tourism and Hotel Management, Dositeja Obradovića Square no. 3, 21000 Novi Sad, Republic of Serbia, Phone: +381 6381447 39, E-mail: porticprof@yahoo.com

6 Marija Knežević Ph.D., Associate Professor, Faculty of Tourism and Hotel Management, Jovana Dučića Street no. 23a, 78000 Banja Luka, Republic of Srpska, Phone: +387 65512 894, E-mail: marija.knezevic@hotmail.com

EP 2017 (64) 1 (359-373) 
of foreign tourists in their perception of local gastronomy and adapting it to the visitors, regardless of the city they visited.

Key words: socio-demographic characteristics, tourists, local gastronomy, The Republic of Serbia

JEL: J1, J19, Z3, Q1, Q19

\section{Introduction}

In the subject literature, the need to research the interest of tourists and food preferences in a destination (Mak et al., 2012a) from the aspect of hospitality and tourism has been emphasized by a greater number of researchers (Chang et al., 2010; Stewart et al., 2008). This increasing interest is fostered by a growing number of destinations, such as Australia, New Zealand, Italy and Singapore, which use all of their culinary resources in promoting and differentiating their own destinations (Chang et al., 2010; Scarpato, 2002).

Mak et al., (2012b) have through the analysis of literature in hospitality and tourism and by synthesis of the results of the consumption of local food, been able to recognize sociodemographic characteristics as a significant factor of influence on food consumption in a tourist destination. According to the authors' knowledge, the conclusion is, based on the analysed literature, that no similar research activities have been conducted so far, except for certain studies which refer to evaluation of hotel service quality (Blešić et al., 2009), satisfaction of foreign tourists staying in city centres (Dwyer et al., 2014), influence that image and total satisfaction with destination have on loyalty of consumers (Armenski et al., 2011), influence of structure of the employees on sensor quality in Belgrade restaurants (Tešanović et al., 2014) as well as possibility of exporting agricultural and alimentary products of plant and animal origin to the tourist boats (Tešanović et al., 2013; Tešanović et al., 2015), which provides space for further research. This study aims to research differences in socio-demographic characteristics of foreign tourists in consumption of local food in the city centres Belgrade and Novi Sad, Republic of Serbia.

\section{Perception of tourists on local gastronomy}

Perception is defined as "the way that one selects, organizes and interprets the stimuli into a meaningful and coherent picture of the world" (Schiffman, Kanuk, 2009). In short, perception is the way "we see the world around us". By the use of their five senses (sight, smell, taste, hearing and touch), consumers are able to perceive the specific attributes of stimuli (e.g. packaging and advertisement) and understand the stimulant further.

In the literature relating to this subject, the attributes (items) of local gastronomy that encourage individuals to taste it, are related to the characteristics of food and beverages that can be perceived by senses (sight, smell, taste, touch and hearing) (Kivela, Crotts, 2006). Responding to these senses, the attributes (questions and items) of local gastronomy in this study include visual appearance, taste and the aroma of food and drinks, the authenticity of the cuisine and its cultural significance. 
Visual appearance - the visual appearance which includes color, shape and the presentation of food, encourages tourists to taste local cuisine. Numerous studies argue that the perception of taste is influenced by the color of food (Stroebele, Castro, 2004; Kivela, Crotts, 2006).

Taste - taste is also an important attribute for the measurement of local food and drinks. Six basically recognizable tastes in gastronomy are: sweet, salty, sour, bitter, spicy (a sensation produced by, among others, hot or chili peppers) and pungent, in Chinese culinary arts (also known as umami) (Kivela, Crotts, 2006).

Aroma - aroma is another attribute appearing as an item for testing the perception of food and beverages. Scientific research suggests that olfactory stimulation plays an important part in the perception of taste; without it one cannot assess food (Gong, 2008). At the same time, the aroma can be the final attribute in measuring local food and beverages related to sensory assessment, which is the overall sensation induced during mastication (e.g. taste, touch, pain and smell) (Hornung, Enns, 1986).

Authenticity of cuisine - authenticity is an important attribute of local gastronomy. It is defined as something that is considered to be true and clear (Tešanović et al., 2009). In the context of cuisine, the authenticity relates to origin.

Cultural significance - researchers believe that the cultural characteristics of food and beverages are one of the reasons why food and beverages consumption is an integral part of the travel experience (Bessière, 1998; Long, 2004).

\section{The importance of socio-demographic characteristics}

Numerous studies (Kim et al., 2009; Khan, 1981; Ignatov, Smith, 2006; Mitchell, Hall, 2003) indicate that demographic and socio-economic characteristics of tourists influence their preferences towards local food. In studies related to consumption of food, sociodemographic characteristics are recognized as significant variables in explaining variations in food consumption in various contexts (Furst et al., 1996; Khan, 1981; Randall, Sanjur, 1981). Based on the conducted research, the text that follows gives a review of socio-demographic variables which occur in the subject literature most frequently:

Gender - the conducted studies point out that female respondents, as compared to male, are more interested in and more excited about degustation of local food when they are on vacation (Kim et al., 2009), that they are much more involved in food related activities (Ignatov, Smith, 2006) and that they are more price sensitive and, at the same time, ready to taste new or unusual fruit and vegetables (Mitchell, Hall, 2003). Also, the studies (Charters, Ali-Knight, 2002; Warde, Martens, 2000) have shown that the tendency to travel abroad, among foreign tourists, is higher among men than women.

Age - the study indicates that the consumption of selection of available food at certain destination is narrowed in elder respondents (Tse, Crotts, 2005) and that they are more health concerned (Kim et al., 2009).

Education - the conducted studies indicate: that the respondents with higher education level 
are more health concerned (Kim et al., 2009), that higher education level increases food related sensation (Glanz et al., 1998) and that the respondents with higher education level have more tendencies towards local food consumption (Zeppel, Hall, 1991). Wadolowska et al., (2008) point out that the respondents with primary education level have a negative or neutral perception of food.

Monthly income - the conducted studies indicate that higher monthly income increases food related sensation (Glanz et al., 1998) and that better job can be an important factor in selection of food (Wadolowska et al., 2008), while Franklin and Crang (2001) point out that the increase of monthly income in households has an important role in tourist demand.

Country - the results of the study (Armenski et al., 2011; Dwyer et al., 2014) point out the increase of foreign tourists from Western European countries into Republic of Serbia. Lukić et al., (2014) mention numerous political, economic and social changes which have influenced a large number of migrations among former Yugoslavian republics, and which has impacts on tourist consumption in Republic of Serbia.

According to the review of the studies conducted so far (Kim et al., 2009; Khan, 1981; Ignatov, Smith, 2006; Mitchell, Hall, 2003; Furst et al., 1996; Randall, Sanjur, 1981), the authors have defined the following hypothesis: There are statistically significant differences in the perception of local gastronomy in relation to socio-demographic characteristics of foreign tourists.

\section{Sample}

The target population included in this research is comprised of foreign tourists whose visits were registered at the territory of Belgrade and Novi Sad, Republic of Serbia. According to the data obtained from the Statistical Office of the Republic of Serbia, Novi Sad was visited by 78,852 (http://webrzs.stat.gov.rs/) foreign tourists during the year 2014 (May-October), while, during the same year, Belgrade was visited by 535,107 (http://webrzs.stat.gov.rs/) foreign tourists, as compared to other tourist destinations such as Kragujevac $(10,680)$ and Subotica $(17,842)$ (Statistical Office of the Republic of Serbia, 2015). During the mentioned months, according to the Institute for Statistics of Serbia (Statistical Office of the Republic of Serbia, 2015), the largest number of foreign tourists was reported in Belgrade and Novi Sad, as compared to Kragujevac and Subotica. Apart from a number of visits of foreign tourists, as one of three criteria considered in selection of a place to conduct research, another two criteria were taken based on Tourism Development Strategy of the Republic of Serbia for 2005-2015 and Law on Tourism ${ }^{7}$, where Belgrade and Novi Sad were defined as tourist destinations of the first category. Therefore, locations of the research are administrative centres Belgrade and Novi Sad.

Sampling method is stratified sample and "simple random sample". According to the data taken from the official tourist statistics (Statistical Office of the Republic of Serbia, 2015), the

7 In accordance with Article 26, Law on Tourism (“Official Gazette RS” No. 36/09, 88/10, 99/2001 $-2^{\text {nd }}$ law 93/2012 and 84/2015). 
only information that the authors were familiar with and which was on their disposal is the number of registered visits of foreign tourists, by location and type of the tourist destination, as prescribed by the official statistics methodology. Stratums are cities in the Republic of Serbia visited by foreign tourists (Statistical Office of the Republic of Serbia, 2015). Because of the aforesaid criteria, the authors decided to take Belgrade and Novi Sad as stratums. After that, each stratum was analysed by means of "simple random sample" procedure. Surveying was carried out through tourist organizations of Belgrade and Serbia, at the territory of Belgrade, while tourist organizations of Novi Sad and Vojvodina carried out the survey in Novi Sad, that is, each foreign tourist that visited any organization was considered a random sample.

The study included 673 respondents of which 332 were in Novi Sad and 342 in Belgrade. Out of the total number of respondents, $51.3 \%$ were male and $48.7 \%$ female (Table 1 ). Table 1 presents the age structure of the sample by city of research. Almost half of the respondents are younger people, 18 to 30 years of age. Other socio-demographic characteristics of the respondents are shown in Table 1.

Table 1. Socio - demographic characteristics of respondents

\begin{tabular}{|c|c|c|c|}
\hline Gender & \begin{tabular}{|l} 
Novi Sad \\
\end{tabular} & Belgrade & Total \\
\hline Male & 188 & 157 & 345 \\
\hline Female & 144 & 185 & 328 \\
\hline \multicolumn{4}{|l|}{ Age categories (in years) } \\
\hline $18-30$ & 178 & 138 & 316 \\
\hline $31-40$ & 76 & 91 & 167 \\
\hline $41-50$ & 38 & 55 & 93 \\
\hline $51-60$ & 30 & 42 & 72 \\
\hline Over 60 & 8 & 16 & 24 \\
\hline \multicolumn{4}{|l|}{ Education level } \\
\hline High school & 60 & 55 & 115 \\
\hline College & 135 & 93 & 228 \\
\hline University - BSc & 70 & 45 & 115 \\
\hline University-MSc & 40 & 65 & 105 \\
\hline University - $\mathrm{PhD}$ & 18 & 76 & 94 \\
\hline \multicolumn{4}{|c|}{ Monthly income by household } \\
\hline Below average & 69 & 47 & 116 \\
\hline Average & 165 & 203 & 368 \\
\hline Above average & 93 & 88 & 181 \\
\hline \multicolumn{4}{|l|}{ Country } \\
\hline Yugoslavian republics & 170 & 136 & 306 \\
\hline Western Europe countries & 122 & 150 & 235 \\
\hline Southern Europe countries & 29 & 36 & 65 \\
\hline Eastern Europe countries & 11 & 20 & 31 \\
\hline
\end{tabular}

Source: authors, based on research 


\section{Instrument}

For the purpose of this study, and following the example of previous studies (Jalis et al., 2009), a questionnaire was used in order to test the difference between socio-demographic characteristics of foreign tourists in the perception of local gastronomy.

For the purpose of this study, the questionnaire was modified and adapted. After the translation of the questionnaire from English to Serbian language, it was subjected to translation again in order to determine trustworthiness (back translation). Further on, an interview with tourism representatives (academic experts, employees in hotels and representatives of tourist organizations), in which experts provided their comments and suggestions on which attributes are to be considered when designing the scale for testing the perception of food, beverages and food culture of Serbia (the perception of local gastronomy). The discussion and interviews with experts had an aim to increase the content validity of the scale and to supplement or change attributes - questions in the questionnaire. Based on qualitative research, it has been concluded that the term "Malaysian food" should be changed to "Local food", since previous studies (Baloglu, McCleary, 1999) have shown that the notion of "local food" contributes to the popularity of a tourist destination and consumption of food. In a research conducted in four Mediterranean countries, Italy has achieved the greatest success using the term "local food" or local cuisine (Baloglu, McCleary, 1999). Further on, it was concluded that items $1,5,6,8,9,23,26,27$ and 30, i.e. the concept of "Malaysian food" should be changed to "Serbian food".

The questionnaire consists of three parts. The first part of the questionnaire represents respondents' consent to complete the questionnaire. Completing the questionnaire is anonymous. The second part relates to demographic and socio-economic characteristics of respondents: gender, age, education level, monthly income and place of residence (country). The third part of the questionnaire relates to the perception of local gastronomy (Table 2), which contains 30 items. In the questionnaire, the concept of collecting and processing stands is defined as the level at which tourist perception of attributes shows perception and acceptability of local food and beverages as an experience related to food culture on a tourist destination. The answers in a questionnaire were measured based on the Likert scale, $1-\mathrm{I}$ strongly disagree, 2 - I mostly disagree, 3 - neutral, 4- mostly agree, 5 - I completely agree.

\section{Procedure}

The survey was conducted on the territory of Belgrade and Novi Sad, during six months of research (May-October) in 2015, and in accordance with reports of the Statistical Office of the Republic of Serbia referring to the structure of foreign tourists by the visited city (Statistical Office of the Republic of Serbia, 2015). It was executed through tourist organizations of Serbia, Belgrade, Vojvodina and Novi Sad. Because the survey was carried out by means of "paper and pen" procedure, it was of utmost importance to have skilful surveyors that would be able to provide good explanations of questions if respondents would ask for it. 


\section{Variables}

Independent variables in this study are the following: gender, age, education, monthly income and country. There is also one dependent variable - perception of local gastronomy.

\section{Methods of data analysis}

Data were analysed by means of software package SPSS: 20 (SPSS, 2008). The missing data were replaced by EM method, while analyses of deviated values indicate that there are none (Tabachnick, Fidell, 2007).

Differences between groups were analysed by means of two-factor ANOVA, with the following factors: city ( 2 levels), gender ( 2 levels), age (5 levels), education (6 levels), monthly income (3 levels) and the country (4 levels). Dependent variable is perception of local gastronomy.

\section{Results}

\section{Descriptive analysis}

Table 2. presents descriptive analysis of the scale items for perception of local gastronomy. The perception of local gastronomy is operationalized as the sum of responses to all 30 items from the third part of the questionnaire. A higher score indicates a better assessment of local gastronomy.

Table 2. Descriptive analysis of the scale items for perception of local gastronomy

\begin{tabular}{|c|c|c|c|c|}
\hline \multirow{2}{*}{ Items } & \multicolumn{2}{|c|}{ Novi Sad } & \multicolumn{2}{|c|}{ Belgrade } \\
\hline & $\mathrm{M}$ & SD & $\mathrm{M}$ & SD \\
\hline 1. Serbia offers great choices of food and beverages & 4.64 & .647 & 4.64 & .66 \\
\hline 2. Most of the Serbian food and beverages are freshly prepared & 4.51 & .675 & 4.47 & .70 \\
\hline 3. Most of the Serbian food and beverages are acceptable & 4.69 & .624 & 4.65 & .69 \\
\hline $\begin{array}{l}\text { 4. Apart from exploring the country, my intention was to learn } \\
\text { about Serbian cuisine, beverages and dining cultures }\end{array}$ & 3.83 & 1.16 & 3.73 & 1.12 \\
\hline $\begin{array}{l}\text { 5. The identity of every Serbian ethnic group can be noticed } \\
\text { through their cuisine }\end{array}$ & 3.93 & 1.00 & 3.82 & 1.00 \\
\hline $\begin{array}{l}\text { 6. Serbia also offers a great variety of snacks (crackers, } \\
\text { preserved foods) }\end{array}$ & 4.23 & .89 & 4.10 & .97 \\
\hline 7. The taste of most Serbian snacks is acceptable & 4.44 & .77 & 4.28 & .88 \\
\hline $\begin{array}{l}\text { 8. Some Serbian food and beverages are recognized } \\
\text { internationally }\end{array}$ & 4.09 & 1.03 & 4.03 & 1.20 \\
\hline $\begin{array}{l}\text { 9. Most of the Serbian snacks are as good as snacks from other } \\
\text { countries }\end{array}$ & 4.34 & .79 & 4.36 & .83 \\
\hline $\begin{array}{l}\text { 10. The taste of local canned beverages is acceptable as the } \\
\text { imported ones }\end{array}$ & 4.25 & .92 & 4.09 & 1.03 \\
\hline $\begin{array}{l}\text { 11. The quality of Serbian canned beverages is as good as } \\
\text { freshly prepared }\end{array}$ & 3.79 & 1.17 & 3.69 & 1.27 \\
\hline 12. Most of Serbian beverages look attractive & 4.22 & .87 & 4.04 & .99 \\
\hline
\end{tabular}




\begin{tabular}{|l|c|c|c|c|}
\hline \multirow{2}{*}{ Items } & \multicolumn{2}{|c|}{ Novi Sad } & \multicolumn{2}{c|}{ Belgrade } \\
\cline { 2 - 5 } & $\mathrm{M}$ & SD & $\mathrm{M}$ & SD \\
\hline 13. Most of the Serbian food is salty & 4.09 & 1.05 & 4.10 & 1.02 \\
\hline 14. Most of the Serbian food tastes good & 4.75 & .55 & 4.71 & .58 \\
\hline 15. Most of the Serbian food is usually served hot & 4.44 & .74 & 4.49 & .74 \\
\hline 16. The aroma of Serbian food is adorable & 4.48 & .75 & 4.45 & .83 \\
\hline 17. Most of the Serbian food contains too much carbohydrate & 3.75 & 1.05 & 3.83 & .99 \\
\hline 18. Most of the Serbian food is too spicy & 3.22 & 1.24 & 3.21 & 1.19 \\
\hline 19. There is too much chili paste in most of the Serbian food & 3.00 & 1.28 & 2.96 & 1.27 \\
\hline 20. Most of the Serbian main dishes are fat/oily & 3.93 & 1.08 & 3.98 & 1.03 \\
\hline 21. Most of the Serbian delicacies and beverages are too sweet & 3.31 & 1.08 & 3.40 & 1.11 \\
\hline 22. Serbian food culture is unique & 4.05 & .96 & 4.22 & .87 \\
\hline $\begin{array}{l}\text { 23. Serbian food culture has its own identity as other European } \\
\text { countries }\end{array}$ & 4.26 & .89 & 4.29 & .86 \\
\hline $\begin{array}{l}\text { 24. The way most Serbian food and beverages are prepared } \\
\text { attracts me }\end{array}$ & 4.30 & .88 & 4.19 & .98 \\
\hline 25. Some of the Serbian cooking styles are attractive & 4.20 & .91 & 4.17 & .97 \\
\hline $\begin{array}{l}\text { 26. The use of traditional equipment in preparing some Serbian } \\
\text { dishes truly portrays a Serbian culture }\end{array}$ & 4.20 & .86 & 4.15 & .89 \\
\hline 27. Serbia is rich in traditional eating manners & 4.30 & .85 & 4.17 & .92 \\
\hline $\begin{array}{l}\text { 28. Different styles of ethnic groups' eating manners represent } \\
\text { the uniqueness of Serbian food culture }\end{array}$ & 4.04 & .90 & 4.04 & .95 \\
\hline $\begin{array}{l}\text { 29. Attending local food festivals/manifestations and trying out } \\
\text { food at street markets are one of the main attractions of Serbian } \\
\text { food culture }\end{array}$ & 4.06 & 1.00 & 4.04 & 1.01 \\
\hline $\begin{array}{l}\text { 30. Preparation and tasting Serbian food at local food festivals/ } \\
\text { manifestations and street markets represent another element of } \\
\text { Serbian food culture }\end{array}$ & 4.15 & .99 & 4.13 & .95 \\
\hline
\end{tabular}

Source: authors, based on research

Table 3. presents descriptive analysis of applied scales. Based on the values of multivariate skewness and kurtosis, it can be concluded that the answers of respondents at the "perception of local gastronomy" scale do not deviate significantly as compared to normal distribution. Cronbach terms are .85 (Table 3), whereas according to the authors' research (Jalis et al., 2009 ) the reliability of the scale is .81 .

Table 3. Descriptive scale indicators

\begin{tabular}{|l|l|l|l|l|l|l|l|l|}
\hline Scale & Min & Max & M & SD & Skew. & Kurt. & K-S & $\alpha$ \\
\hline Perception & 74.00 & 151.23 & 122.96 & 12.41 & -.800 & 1.101 & $0.097^{*}$ & 0.85 \\
\hline
\end{tabular}

Note. ${ }^{*} p$ < 0.1: Min. - minimal score; Max. - maximal score; $M$ - arithmetic mean; SD - standard deviation; Skew. - Skewness; Kurt. - Kurtosis; K-S-Kolmogorov-Smirnov statistics; $\alpha$-scale reliability measured by internal consistency

Source: Processing data from survey research 
The results of T-test for independent samples show that there is none statistically significant difference between foreign tourists who visited Belgrade ( $\mathrm{M}=122.45, \mathrm{SD}=12.29)$ and Novi $\mathrm{Sad}(\mathrm{M}=123.48, \mathrm{SD}=12.56)$. The value of T-test is 0.23 , and it is not statistically significant $(p=0.27)$. The results have shown that foreign tourists who visited Novi Sad have positively assessed local gastronomy in a somewhat more pronounced degree in relation to tourists who visited Belgrade.

\section{Differences in demographic characteristics of tourists in perception of local gastronomy}

The results of two-factor analysis with the factors: gender ( 2 levels) and city ( 2 levels) show that there is no statistically significant interaction of gender and city $(\mathrm{F}(1,669)=0.67$, $\mathrm{p}=0.42)$, nor the main effects of gender $(\mathrm{F}(1,669)=0.50, \mathrm{p}=0.48)$ and city $(\mathrm{F}(1,669)=0.95$, $\mathrm{p}=0.33$ ). On the other hand, male tourists from Novi Sad show only a tendency towards a more positive assessment of local gastronomy, compared to other groups of respondents.

The results of two-factor analysis including the factors: age (5 levels) and city (2 levels) show that there is no significant interaction between age and city $(F(4,662)=0.45, p=0.77)$, nor the main effect of the city $(\mathrm{F}(1,662)=1.89, \mathrm{p}=0.16)$, but there is a significant main effect of age $\left(\mathrm{F}(4,662)=5.58, \mathrm{p}<0.00, \eta_{\mathrm{p}}^{2}=0.02\right)$. Post hoc test (Tukey's HSD) shows that there is a significant difference between respondents in the category of $18-30$ years $(\mathrm{M}=122.48)$ and the respondents who fall into the category 51-60 years $(M=126.85, \mathrm{p}<0.05)$. Further on, the same post hoc test shows that there is a difference between respondents who are 31-40 years old ( $\mathrm{M}=124.97)$ and the respondents who are $41-50$ years old $(\mathrm{M}=124.97, \mathrm{p}<0.02)$, as well as in relation to respondents who fall in the category between 51-60 years of age $(\mathrm{p}<0.00)$.

The results of two-factor analysis of the factors: education ( 5 levels) and city ( 2 levels) show that there is no statistically significant interaction between education and city $(\mathrm{F}(4$, $662)=1.16, p=0.33)$, neither is there the main effect of the city $(F(1,662)=0.17, p=0.68)$, but there is a significant main effect of education $\left(F(4,662)=2.52, p<0.05, \eta_{p}^{2}=0.04\right)$. The results indicate that regardless of the city they were staying in, there is a significant difference between the respondents of different educational level in the perception of local gastronomy. Post hoc test (Fisher's LSD), has shown that there is a significant difference between respondents who have high school $(M=125.85)$ and the ones who have a university degree - BSc $(\mathrm{M}=122.13 ; \mathrm{p}<0.05)$, the respondents who have high school and the ones who have university degree $-\mathrm{MSc}(\mathrm{M}=121.73$; $\mathrm{p}<0.01)$ and respondents who have high school and the ones who have a university degree $-\mathrm{PhD}(\mathrm{M}=121.27 ; \mathrm{p}<0.00)$.

The results of two-factor analysis with the factors: monthly income (3 levels) and city (2 levels) show a statistically significant interaction between monthly income and city ( $\mathrm{F}(2$, $\left.659)=8.07, \mathrm{p}<0.00, \eta_{\mathrm{p}}^{2}=0.02\right)$, as well as not that significant main effects of monthly income $(\mathrm{F}(2,665)=1.80, \mathrm{p}=0.16)$ and the city $(\mathrm{F}(1,665)=0.09, \mathrm{p}=0.76)$. Post hoc test (Tukey's HSD) shows that there is a difference between respondents from Novi Sad with below average income $(M=119.62)$ and the ones with average income $(M=124.91 ; \mathrm{p}<0.05)$. Also, a significant difference was noticed between respondents from Novi Sad with below 
average income and respondents from Belgrade with the same income $(M=126.73 ; p<0.05)$ in the perception of local gastronomy. Further on, differences have been shown between the respondents from Belgrade with below average income and with above average income $(\mathrm{M}=119.67 ; \mathrm{p}<0.01)$ in the perception of local gastronomy.

The results of two-factor analysis of the factors: country (4 levels) and city (2 levels) indicate that there is no significant interaction of variables of country and city $(F(4,664)=0.70$, $\mathrm{p}=0.59)$ nor is there a significant effect of the city $(\mathrm{F}(1,664)=1.01, \mathrm{p}=0.31)$. However, there is a significant main effect of the variable of country $(F(4,664)=8.45, p<0.001$, $\left.\eta_{p}^{2}=0.04\right)$ when it comes to the perception of local gastronomy. These results show that respondents from various countries differ in the perception of local gastronomy, regardless of the city they visited. Post hoc test (Tukey's HSD) shows that respondents from the countries of former Yugoslavian countries $(\mathrm{M}=125.89)$ differ from respondents from Western Europe countries $(\mathrm{M}=120.06 ; \mathrm{p}<0.01)$, as well as from respondents from Southern Europe countries $(M=120.13 ; p<0.05)$. In other words, respondents originating from the countries of Yugoslavian republics at a higher level asses local gastronomy in a more positive way, in relation to above mentioned groups of countries.

\section{Discussion}

The results indicate that there are differences between variables: age, level of education, monthly income and country in the perception of local gastronomy, but not in variable gender. The findings indicate that there is only a tendency that men who have visited Novi $\mathrm{Sad}$, in relation to other groups of respondents are more inclined in the perception of local gastronomy. The obtained results are contrary to previous researches. However, the results of the study (Charters, Ali-Knight, 2002; Warde, Martens, 2000) show that in relation to women, men are more inclined to travel abroad, as for foreign tourists. The findings indicate that there is a difference between age variable in the perception of local gastronomy. More precisely, respondents who belong to an older category, assess local gastronomy in a more positive way, which is in accordance with previous researches. Possible differences between groups of respondents with level of education variable, where respondents with a lower education level assess local gastronomy in a more positive way, can be explained by the fact that they were willing to try more food and drinks compared to other groups of respondents. It can be assumed that respondents with lower level of education are less concerned about health than respondents with a higher level of education (Kim et al., 2009). The obtained results are contrary to previous researches. The results of monthly income variable indicate a different trend of differences: respondents from Novi Sad with below average income tend to positively assess local gastronomy to a lesser extent, in relation to respondents with higher monthly income. On the other hand, respondents from Belgrade with below average income tend to positively assess local gastronomy to a higher extent, in relation to respondents with a higher monthly income. Previous research (Glanz et al., 1998; Wadolowska et al., 2008) point out that a higher monthly income and a better job increase the experience and choice of food, which is in accordance with results obtained in Novi Sad. However, the findings in Belgrade are contrary to the above-mentioned research. It can be assumed that respondents with a 
higher monthly income did not get "proper value for money" or their expectations were not satisfied. The findings indicate that the greatest number of foreign tourists who participated in this research is from former Yugoslavian countries and secondly from Western European countries. A justification for this can be found in the fact that The Republic of Serbia suffered many changes during the 90s in the XX century (Lukić et al., 2014), thus, the biggest number of foreign tourists comes from former Yugoslavian countries. In addition to this, previous studies confirm a tendency for visits of the Republic of Serbia by tourists from Western European countries (Armenski et al., 2011; Dwyer et al., 2014), which is in accordance with obtained results. According to authors' findings, differences between Belgrade and Novi Sad in the perception of local gastronomy have not been examined so far (Armenski et al., 2011; Blešić et al., 2009; Dwyer et al., 2014; Tešanović et al., 2014; Tešanović et al., 2013; Tešanović et al., 2015), so this paper provides a new insight into the significance of local gastronomy at the localities tested.

The findings of the study indicate that there are statistically significant differences between socio-demographic characteristics of foreign tourists in relation to variables of age, level of education, monthly income and country, but not gender, in the perception of local gastronomy, which makes the hypothesis partially supported.

\section{Research limitations}

One of the limitations of the study is the sample. Although the respondents involved in this study had different experiences in local gastronomy and were of different nationalities, majority of tourists that took part in the study come from the countries of former Yugoslavian republics and Western European countries. Also, the research included two tourist centres, which means that it excludes other tourist destinations where local food can be found as well. Therefore, tourist destinations such as spa centres and mountain resorts should be taken into consideration in future studies.

\section{Conclusion}

The significance of this research comes from the fact that so far there has not been a similar research regarding Republic of Serbia and the cities of Belgrade and Novi Sad. The results indicate which socio-demographic characteristics of foreign tourists are important for future development plans and promotions of a given destination on a target market. At the same time, the findings indicate the importance of socio-demographic variables in the study of local gastronomy as a significant component of the tourism product. For example, if companies (hotels, restaurants etc.) want to increase the perception of local gastronomy, they can apply this instrument to examine the structure of tourists, that is socio-demographic characteristics in order to track their requirements and needs.

The obtained data can be of use to various market subjects in order to establish special bodies in order to regulate and monitor the work of companies and tourist organizations, disclosure of inappropriate enterprise behavior, publishing information related to local gastronomy and dealing with tourists' complaints. Monitoring reduces dissatisfaction and improves positive 
evaluation of local gastronomy. At the same time, this can increase overall satisfaction of tourists with chosen destinations. In addition, this research makes it possible for the sectors of economy and government to understand better the significance of local gastronomy, as part of the destination, and thus how to improve acceptability with foreign tourists.

The findings of this study indicate that there are no differences between the cities of Belgrade and Novi Sad in the perception of local gastronomy, which can serve as the starting point to enter the partnership between the cities and for the development of a common strategy. First of all, the cooperation of tourist organizations and other sector, first at the local and then at regional level, can take responsibility for monitoring the work of companies dealing with food and beverages at a certain destination.

The results of the research rely on single-year research. However, taking into consideration the very concept of the research, it would be more appropriate to carry out longitudinal, multi-year research with the same group or respondents and repeated measures, in order to form a clear and precise image of factors influencing local food consumption. Repeated studies would require forming of the sample population that would participate in the research during the period of 5 to 10 years. The results of longitudinal research would have significant theoretical, but also practical implications for a tourist destination, particularly from the aspect of long-term planning of marketing strategies and creation of tourist sensation and feeling towards changeable requests and needs of tourist demand.

\section{Literature}

1. Armenski, T., Gomezelj, D. O., Djurdjev, B., Deri, L., Aleksandra, D. (2011): Destination competitivenes: A challenging process for Serbia, Human Geographies, vol. 5, no. 1, pp. 19.

2. Baloglu, S., McCleary, K. W. (1999): US international pleasure travelers'images of four Mediterranean destinations: A comparison of visitors and nonvisitors, Journal of travel research, vol. 38, no. 2, pp. 144-152.

3. Bessière, J. (1998): Local development and heritage: traditional food and cuisine as tourist attractions in rural areas, Sociologia ruralis, vol. 38, no. 1, pp. 21-34.

4. Blešić, I., Romelić, J., Garača, V. (2009): An investigation of the expectations and perceptions of consumers about the quality of services in the spa hotels of West Morava region, Glasnik Srpskog geografskog drustva, vol. 89, no. 1, pp. 103-114.

5. Chang, R. C., Kivela, J., Mak, A. H. (2010): Food preferences of Chinese tourists, Annals of Tourism Research, vol. 37, no. 4, pp. 989-1011.

6. Charters, S., Ali-Knight, J. (2002): Who is the wine tourist?, Tourism management, vol. 23, no. 3, pp. 311-319.

7. Dwyer, L., Dragićević, V., Armenski, T., Mihalič, T., Knežević Cvelbar, L. (2014): Achieving destination competitiveness: an importance-performance analysis of Serbia, Current Issues in Tourism, pp. 1-28.

8. Franklin, A., Crang, M., (2001): The trouble with tourism and travel theory, Tourist Studies, vol. 1, no. 1, pp. 5-22.

9. Furst, T., Connors, M., Bisogni, C. A., Sobal, J., Falk, L. W. (1996): Food choice: a 
conceptual model of the process, Appetite, vol. 26, no. 3, pp. 247-266.

10. Glanz, K., Basil, M., Maibach, E., Goldberg, J., Snyder, D. (1998): Why Americans eat what they do: taste, nutrition, cost, convenience, and weight control concerns as influences on food consumption, Journal of the American Dietetic Association, vol. 98, no. 10, pp. 1118-1126.

11. Gong, H. N. (2008): How is the arrival of things possible?, Frontiers of Philosophy in China, vol. 3, pp. 389-408.

12. Hornung, D. E., Enns, M. P. (1986): The contributions of smell and taste to overall intensity: A model, Perception \& psychophysics, vol. 39, no. 6, pp. 385-391.

13. Ignatov, E., Smith, S. (2006): Segmenting Canadian culinary tourists, Current Issues in Tourism, vol. 9, no. 3, pp. 235.

14. Jalis, M. H., Zahari, M. S., Zulkifly, M. I., Othman, Z. (2009): Malaysian gastronomic tourism products: Assessing the level of their acceptance among the western tourists, South Asian Journal of Tourism and Heritage, vol. 2, no. 1, pp. 31-44.

15. Khan, M., (1981): Evaluation of food selection patterns and preferences, CRC Critical Reviews in Food Science and Nutrition, vol. 15, pp. 129-153.

16. Kim, Y. G., Eves, A., Scarles, C. (2009): Building a model of local food consumption on trips and holidays: A grounded theory approach, International Journal of Hospitality Management, vol. 28, no. 3, pp. 423-431.

17. Kivela, J., Crotts, J. C. (2006): Gastronomy tourism: A meaningful travel market segment, Journal of Culinary Science \& Technology, vol. 4, no. 2-3, pp. 39-55.

18. Law on Tourism (“Official Gazette RS” No. 36/09, 88/10, 99/2001 -2 ${ }^{\text {nd }}$ law 93/2012 and 84/2015).

19. Long, L. M. (2004): Culinary Tourism, The University Press of Kentucky, Kentucky.

20. Lukić, T., Penjišević, I., Đerčan, B., Đurđev, B., Bubalo Živković, M., Armenski, T. (2014): Politics in the Balkan countryside: case study in Serbia, Eastern European Countryside, vol. 20, pp. 99-124.

21. Mak, A. H., Lumbers, M., Eves, A. (2012a): Globalisation and food consumption in tourism, Annals of Tourism Research, vol. 39, no. 1, pp. 171-196.

22. Mak, A. H., Lumbers, M., Eves, A., Chang, R. C. (2012b): Factors influencing tourist food consumption, International Journal of Hospitality Management, vol. 31, no. 3, pp. 928-936.

23. Mitchell, R. D., Hall, C. M. (2003): Seasonality in New Zealand winery visitation: An issue of demand and supply, Journal of Travel \& Tourism Marketing, vol. 14, no. 3-4, pp. 155-173.

24. Randall, E., and Sanjur, D. (1981): Food preferences-their conceptualization and relationship to consumption, Ecology of food and nutrition, vol. 11, no. 3, pp. 151161.

25. Scarpato, R. (2002): Gastronomy as a tourist product: The perspective of gastronomy studies, Tourism and gastronomy, pp. 51-70.

26. Schiffman, L., Kanuk, L. (2009): Consumer behavior (10 ${ }^{\text {th }}$ edition). New Jersey: Prentice Hall. 
27. Statistical Office of the Republic of Serbia, (2015). (available at: http://webrzs.stat. gov.rs/WebSite/Public/PageView.aspx?pKey=182. Retrieved: 25.9.2015).

28. Stewart, J. W., Bramble, L., Ziraldo, D. (2008): Key challenges in wine and culinary tourism with practical recommendations, International Journal of Contemporary Hospitality Management, vol. 20, no. 3, pp. 303-312.

29. Stroebele, N., De Castro, J. M. (2004): Effect of ambience on food intake and food choice, Nutrition, vol. 20, no. 9, pp. 821-838.

30. Tabachnick, B. G., Fidell, L. S. (2007): Using Multivariate Statistics, 5th edn., Pearson, Boston, MA.

31. Tešanović, D., Kalenjuk, B., Blešić, I. (2009): Struktura gastronomske ponude na salašima i njen uticaj na razvoj seoskog turizma, Turističko poslovanje, vol. 4, pp. 103-110.

32. Tešanović, D., Krasavčić, M., Kalenjuk, B., Portić, M., Gagić, S. (2014): The influence of the structure of employees on sensory quality of restaurants food, British Food Journal, vol. 116, no. 3, pp. 527 - 543.

33. Tešanović, D., Vuksanović, N., Kalenjuk, B., Portić, M. (2015): Tourist Ships On The Danube As An Opportunity For Export OfMeat And Meat Products, Economics of Agriculture, vol. 62, no. 2, pp. 527-542.

34. Tešanović, D., Vuksanović, N., Kalenjuk, B., Vukić, M., Gagić, S. (2013): Danube tourist ships as an opportunity for export of agricultural and food products, Economics of Agriculture, vol. 60, no. 1, pp. 179-194.

35. Tourism Development Strategy of the Republic of Serbia (2005). Ministarstvo trgovine, turizma i usluga, Republike Srbije. Horwath consulting i Ekonomski fakultet, Univerzitet u Beogradu.

36. Tse, P., Crotts, J. C. (2005): Antecedents of novelty seeking: International visitors' propensity to experiment across Hong Kong's culinary traditions, Tourism Management, vol. 26, no. 6, pp. 965-968.

37. Wadolowska, L., Babicz-Zielinska, E., Czarnocinska, J. (2008): Food choice models and their relation with food preferences and eating frequency in the Polish population, Food Policy, vol. 33, pp. 122-134.

38. Warde, A., Martens, L. (2000): Eating out: Social differentiation, consumption and pleasure, Cambridge University Press.

39. Zeppel, H., Hall, C. M. (1991): Selling art and history: cultural heritage and tourism, Journal of Tourism Studies, vol. 2, no. 1, pp. 29-45. 


\title{
SOCIO - DEMOGRAFSKE KARAKTERISTIKE KAO DETERMINENTE RAZLIKA U PERCEPCIJI LOKALNE GASTRONOMIJE ${ }^{8}$
}

\author{
Nikola Vuksanović, Dragan Tešanovićc ${ }^{10}$, Bojana Kalenjuk ${ }^{11}$, Milijanko Portićc ${ }^{12}$, \\ Marija Knežević ${ }^{13}$
}

\section{Rezime}

Cilj studije je ispitivanje razlika u percepciji lokalne gastronomije u odnosu na socio demografske karakteristike stranih turista sa uvažavanjem gradskih centara u kojima su boravili, Beograd i Novi Sad u Republici Srbiji. Istraživanje je sprovedeno na uzorku od 673 ispitanika. Nalazi ove studije ukazuju na važnost socio - demografskih varijabli za ispitivanje lokalne gastronomije kao značajne komponente turističkog proizvoda. Ispitivanje je uključilo i utvrdivanje uticaja grada u kojem su turisti boravili. Razlike su ispitane dvofaktorskom analizom varijanse. Dobijeni rezultati pokazuju da postoje razlike između starosnih grupa, nivoa obrazovanja, mesečnih prihoda i država iz kojih dolaze strani turisti, dok ne postoji razlika između polova u odnosu na percepciju lokalne gastronomije. Istovremeno, nalazi ukazuju da ne postoje razlike u percepciji lokalne gastronomije između gradova Novog Sada i Beograd. Rezultati potvrđuju ranije studije i ukazuju na značaj socio-demografskih karakteristika stranih turista u percepciji lokalne gastronomije, te $i$ prilagođavanje iste posetiocima, bez obzira na grad koji su posetili.

Ključne reči: socio - demografske karakteristike, turistu, lokalne gastronomije, Republika Srbija

8 Ovaj rad je deo projekata III-46009 i III-46005 koje finansira Ministarstvo prosvete, nauke i tehnološkog razvoja Republike Srbije.

9 Nikola Vuksanović, M.Sc, asistent, Visoka škola strukovnih studija za menadžment i poslovne komunikacije, Mitropolita Stratimirovića 110, 21205 Sremski Karlovci, Srbija, Telefon: +381 63 1968 770, E-mail: vuksanovicnikola@yahoo.com

10 Redovni profesor, dr Dragan Tešanović, Prirodno-matematički fakultet, Departman za geografiju, turizam i hotelijertsvo, Trg Dositeja Obradovića br. 3, 21000 Novi Sad, Srbija, Telefon: +381 63 541 436, E-mail: tesanovic.dragan@gmail.com

11 Docent, dr Bojana Kalenjuk, Prirodno-matematički fakultet, Departman za geografiju, turizam i hotelijertsvo, Trg Dositeja Obradovića br. 3, 21000 Novi Sad, Srbija, Telefon: +381 6419902 35, E-mail: bojanakalenjuk@yahoo.com

12 Vanredni profesor, dr Milijanko Portić, Prirodno-matematički fakultet, Departman za geografiju, turizam i hotelijertsvo, Trg Dositeja Obradovića br. 3, 21000 Novi Sad, Srbija, Telefon: +381 63 81447 39, E-mail: porticprof@yahoo.com

13 Vanredni profesor, dr Marija Knežević, Fakulteta za turizam i hotelijerstvo, 78000 Banja Luka, Republika Srpska, Ulica Jovana Dučića br. 23a, Telefon: +387 65512 894, E-mail: marija.knezevic@hotmail.com

EP 2017 (64) 1 (359-373) 
ECONOMICS OF

AGRICULTURE

\section{CONTENT}

1. Željko Anđelković, Aleksandra Dragin, Sanja Božić, Kristina Košić

EMOTIONAL EXHAUSTION AND JOB SATISFACTION OF TOUR GUIDES IN RURAL AREAS . . . . . . . . . . . . . . 11

2. Sanja Đukić, Danica Glavaš-Trbić, Nikola Banjac

MANAGEMENT PROBLEMS OF RURAL DEVELOPMENT IN FRUŠKA GORA . . . . . . . . . . . . . . . . . . . . 27

3. Ivana Ilić, Bojan Krstić, Sonja Jovanović

ENVIRONMENTAL PERFORMANCES OF AGRICULTURE IN THE EUROPEAN UNION COUNTRIES . . . . . . . . . . . . . 41

4. Nataša Kljajić, Jonel Subić, Zorica Sredojević

PROFITABILITY OF RASPBERRY PRODUCTION

ON HOLDINGS IN THE TERRITORY OF ARILJE. . . . . . . . . . . 57

5. Aleksandar Maksimović, Zoran Grgić, Ferhat Ćejvanović

MULTI-ATTRIBUTE ANALYSIS OF ORCHARD ACCORDING

TO THE INTEGRATED PRODUCTION CONCEPT . . . . . . . . . . 69

6. Ozrislava Milinković, Branislav Jakić, Slobodan Vuksanović,

Dragana Macura, Milica Šelmić

MULTI- CRITERIA DECISION BASED APPROACH

TO SELECTING THE TYPE OF INDUSTRIAL HALLS

USED IN FOOD INDUSTRY $\ldots \ldots \ldots \ldots$. . . . . . . . . . 81

7. Gordana Nikić, Ljubiša Stamatović, Azra Sućeska

EMOTIONAL COMPETENCIES AND PERSONALITY

TRAITS OF MANAGERS IN MODERN AGROBUSINESS. . . . . . . .97

8. Vladimir Obradović, Nemanja Karapavlović

FINANCIAL REPORTING OF COMPREHENSIVE INCOME

IN THE FOOD AND BEVERAGE SECTOR

IN THE REPUBLIC OF SERBIA . . . . . . . . . . . . . . 113 
9. Aleksandar Ostojić, Nebojša Savić, Željko Vaško

CONSUMER ATTITUDES

ON BUYING FISH IN BANJA LUKA . . . . . . . . . . . . . . . 129

10. Radivoj Prodanović, Boris Kuzman, David Jovović, Lazar Ozegović

MARKET AND TRADE OF ORGANIC FRUITS IN SERBIA $\ldots . . .141$

11. Predrag Vukadinović, Aleksandar Damnjanović, Ljiljana Dimitrijević

ANALYSIS OF THE SALES AND INCOMES BETWEEN

DIFFERENT CATEGORIES OF AGRICULTURAL PRODUCTS . . . 157

12. Jugoslav Aničić, Svetlana Vukotić, Goran Maksimović

THE POSSIBILITIES AND LIMITATIONS

OF ENTREPRENEURSHIP DEVELOPMENT

IN AGRICULTURE IN SERBIA . . . . . . . . . . . . . . 171

13. Željko Bjelajac, Marijana Dukić - Mijatović, Joko Dragojlović

FOOD SAFETY AS ONE OF THE MAIN SAFETY $P$

REOCCUPATIONS OF A MODERN MAN . . . . . . . . . . . . . 191

14. Milan Bradić, Ljiljana Kosar, Lukrecija Djeri, Svetlana Vukosav, Vuk Garača

ECO-LABELLING OF ACCOMMODATION FACILITIES

AND ITS PERCEPTION BY RURAL TOURISTS:

CASE STUDY OF VOJVODINA . . . . . . . . . . . . . . 205

15. Vaso Jegdić, Iva Škrbić, Srđan Milošević

MODELS OF ENTREPRENURSHIP DEVELOPMENT

IN RURAL TOURISM DESTINATIONS IN VOJVODINA . . . . . . . 221

16. Duško Kuzović

MUSEUM OF VERNACULAR ARCHITECTURE OF WESTERN SERBIA

- Representative curtilages of the area surrounding middle

course of the river Drina and Podgorina . . . . . . . . . . . 239

17. Branko Mihailović, Zoran Simonović, Nikola Ćurčić

AGRICULTURAL RESOURCES AND DEVELOPMENT

PRIORITIES OF THE MUNICIPALITY OF STARA PAZOVA. . . . . 259

18. Radmilo Nikolić, Aleksandra Fedajev, Vidoje Stefanović, Silvana Ilić

THE AGRICULTURE SECTOR IN WESTERN BALKANS

- SOME CHARACTERISTICS OF DEVELOPMENT. . . . . . . . . . 275

19. Vladimir Njegomir, Rajko Tepavac, Nenad Ivanišević

ALTERNATIVE SOURCES OF FINANCING

ENTREPRENEURIAL UNDERTAKINGS IN AGRICULTURE . . . 295

Economics of Agriculture, Year 64, No. 1 (1-404) 2017, Belgrade 
20. Daniela Nuševa, Kristina Mijić, Dejan Jakšić

THE PERFORMANCES OF COFFEE PROCESSORS

AND COFFEE MARKET IN THE REPUBLIC OF SERBIA . . . . . . 307

21. Svetlana Roljević Nikolić, Predrag Vuković, Biljana Grujić

MEASURES TO SUPPORT THE DEVELOPMENT OF ORGANIC

FARMING IN THE EU AND SERBIA . . . . . . . . . . . . 323

22. ŽeljkoVojinović, Vera Zelenović, DragoCvijanović

PROGRAM OF STATE SUPPORT

TO AGRICULTURAL CREDITING. . . . . . . . . . . . . . . . 339

23. Nikola Vuksanović, Dragan Tešanović, Bojana Kalenjuk,

Milijanko Portić, Marija Knežević

SOCIO-DEMOGRAPHIC CHARACTERISTICS

AS DETERMINANTS OF DIFFERENCES

IN PERCEPTION OF LOCAL GASTRONOMY . . . . . . . . . . . . 359 